\title{
Poverty - The road ahead. A theological perspective 1
}

\author{
P G J Meiring
}

\begin{abstract}
The article focuses on the role of the Church in combating poverty in South Africa. After a brief discussion of Biblical perspectives on poverty, an overview of the involvement of the Church throughout history, especially during the second half of the 20 th century, is given. Three different approaches adopted by the Dutch Reformed Church (Nederduitse Gerformeerde Kerk) in this respect are analyzed. The latter part of the article is devoted to a discussion of the road ahead, seen by the author as a road of faith, a road of hope and a road of love.
\end{abstract}

How does one recognize a christian? When does a body of people truly become recognizable as the church, the body of Christ in the world? Many answers may be given to these questions, but none more apt and thought provoking than the answer provided by the Lord himself. In Matthew 25 Jesus addresses the question eschatologically. In the final analysis, on the last day, He says, it will become abundantly clear whom the Lord will recognize as his own:

"When the Son of Man comes as King and all the angels with Him, He will sit on his royal throne ... He will put the righteous people on his right and the others on his left. Then the king will say to the people on his right: "Come you that are blessed by my Futher! Come and possess the kingdom which has been prepared for you... I was hungry and you fed $M e$, thirsty and you gave Me a drink; I was a stranger and you received Me in your homes, naked and you clothed Me; I was sick and you took care of $\mathrm{Me}$, in prison and you visited Me... I tell you, whenever you did this for one of the least important of these brothers of Me, you did it for Me!"

Then He will say to those on the left: "Away from Me, you that are under God's curse... I was hungry and you would not feed Me, thirsty but you would not give Me a drink. I was a stranger... naked... in prison, but you would not take care of Me... I tell you, whenever you refused to help one of these least important ones, you refused to help Me" (Matthew 25:3146).

In a sense Jesus' words may be read as a summation of his own ministry. But it equally well reflects the Old Testament message of God, the merciful and loving 
God, who cares for people, the champion of the poor and the downtrodden, the marginalized of society.

The past two decades - during which the universal plight of the poor has landed on the world's agenda with unprecedented force - scores of studies have been published on the biblical teaching on poverty ${ }^{2}$. All of them underline the fact both in Old and New Testaments - in Mosaic Law, in the Psalms and teachings of the prophets, in the ministry of Jesus and the apostles - a significant focus was set on the poor. "The whole Bible", says Gustavo Gutierrez ${ }^{3}$ from Latin America, "beginning with the story of Cain and Abel, mirrors God's predilection for the weak and the abused of human history."

The God of the Old Testament is proclaimed to be a merciful God, the protagonist of the weak, of widows and orphans and strangers. But $\mathrm{He}$ is also proclaimed as the righteous God who judges in favour of the oppressed, who provides food and shelter for the hungry, who protects strangers (Psalm 146:7-9). Small wonder, then, to have to listen repeatedly in the Old Testament to the prophets' stern warnings and admonitions against all who wrong the poor, who sell the helpless into slavery, who trample down the weak and the helpless (Amos 2:6). Israel, the covenant people of God, were supposed to bear His image, to emulate His love and concern towards the poor ${ }^{4}$.

Jesus Christ, in the New Testament, is similarly introduced as the friend and protector of the poor and the marginalized. The Gospels proclaim Him as the Messiah, the One who came to bring good news to the poor, to proclaim liberty to the captives, recovery of sight to the blind, to set free the oppressed (Luke 4:18ff). Jesus put Himself in the service of the poor, He (in the words of Paul) "who rich as He was, made himself poor for our sake, in order to make us rich by means of his poverty" (II Cor 8:9).

The first Christians, according to the Book of Acts, as well as the New Testament epistles, understood their Master's message well. They tried to live by this message, becoming sensitive to the needs of others, sharing whatever resources they had. When one part of the body, Jerusalem congregation, was threatened by famine, Paul organized the first ecumenical inter-church aid project, a collection to which all the brothers and sisters in Asia Minor and Greece and Rome, were privileged to contribute. The so called "isotes " principle, calling for equality and fairness when it comes to the sharing of resources (2 Cor 8:13-15), was introduced by Paul, and accepted by the church5. 


\section{MODELS AND ANSWERS}

Much of this ethos was preserved during the first centuries in the history of the church. After Constantine, the first Roman emperor to embrace Christianity as state religion, the situation changed. The church grew richer and more privileged, the gospel message more compromised, and the poor and the destitute increasingly neglected or treated condescendingly.

There were glorious exceptions to the rule, of course. During the earlier centuries the Monastic Movement kept the ideal alive, as did Basil the Great, and Augustine, and Chrysostom, who never missed a chance in exhorting the faithful to take note of the poor. In later centuries missionaries of all persuasions - the Catholic de las Casas, the German Pietists, the Basel and CMS Missionaries - called the church's attention to the poor. By and large, however, the churches tended to claim a type of "extra-territoriality", a position above the flux and conflicts of history, merely spelling our gospel principles. Social ills had to be remedied, yes, but without challenging societal and political macrostructures ${ }^{6}$.

All this was to change dramatically during the second half of the 20th century. Confronted by the enormous problems of the post war world, Christians came to realise that the traditional approach would not suffice, that the evils they had to struggle against, the principalities and the powers, were not just in the heavens, they were incarnate on earth as demonic forces within the structures of society7. Poverty was a result of an unjust society, of unsound economic and political strategies, and should be tackled as such. Churches came to realise that neither the traditional charity model nor the so-called comprehensive approach in missions (whereby evangelisation was accompanied by educational, medical and agricultural efforts) were adequate any longer. A more fundamental strategy was needed to combat social injustice. The new challenge, and the new catch phrase, was development. Governments of the First and Second Worlds were to contribute to the solution of Third World problems by pouring their resources into ambitious development projects. Hurriedly, Western Churches and mission agencies got onto the bandwagon as well 8 .

The optimism of this "First Development Phase", however, was short lived ${ }^{9}$. Because it was based on flawed assumptions - that one way Western modernization would solve all the world's evils; that development aid could be foisted upon Third World societies who often have not even been consulted in the process, that nothing in the First World needed to change - the project (according to David Boschs' analysis) miscarried disastrously. Politically, too, the mood in Latin American and other Third World countries have changed. Development aid had lost its appeal. Revolution, not development, was in the air. Ecclesiastically and 
theologically the cry was for liberation theology. Poverty - politicians as well as liberation theologians contended - would not be uprooted by pouring more technological know-how into poor countries, but by removing the root cause of injustice. Not waiting for the West to endorse such a project, the poor of the world would take their destiny in their own hands, to liberate themselves! Development implied evolutionary continuity with the past; liberation implied a clean break, a new beginning 10 .

As could have been expected, these events exerted a profound influence on theological discussions in church circles across the globe. Since the early 1960 's the Roman Catholic Church came to the fore with strong statements on the church's social calling. Pope John XXIII's two encyclicals Mater et Magistra (1961) and Pacem in terris (1964), and especially the important Second Vatican Council document Gaudium et Spes (1965) as well as Pope Paul VI's encyclical Popularum Progressio made an earnest appeal to Christians to became involved in combating poverty. The main emphasis, however, still was on development, on economic and structural changes "from above". The Second and Third General Conferences of Latin American Bishops at Medellin, Colombia (1968), and Puebla, Mexico (1979) put a definite stop to that. Liberation theology was on the march. It was at Puebla that the phrase "God's preferential option for the poor" was first coined, the phrase that found its way into many a document and confession since. The poor, it was stated, though not being the only ones, are the first on whom God focuses his attention. The church therefore had no option, but to demonstrate its solidarity with the poor. The poor, in the words of Latin American theologian Hugo Assman, had "an epistemological privilege", they were the new interlocutors of theology, its new hermeneutical locus ${ }^{11}$.

In ecumenical protestant theology a similar line was adopted. As was the case with their Catholic counterparts, Protestant theologians in the 1960's and 1970's were still convinced that social and economical development, western style, was the solution to the world's problems. Even the WCC Uppsala Assembly (1968), in spite of its radical stance on may socio-political issues, seemed almost oblivious to the fact that the entire philosophy of development had been challenged by Third World christians. At Bangkok (1973), Nairobi (1975) and especially Melbourne (1980) new voices, new emphases, were heard. The poor, at Melbourne, were put in the very centre of theological and missiological reflection. Not development from above but the "unalloyed affirmation of solidarity with these, is today a central and crucial priority of Christian mission". As had happened in Catholic theology, the poor, at Melbourne, became the dominant hermeneutical category, in the words of Emilio Castro, "the missiological principle par exellence", the "missionary yardstick"12. 
Since the 1980's, interestingly enough, yet another new development became evident in Catholic as well as in Protestant circles, calling for a more nuanced approach in dealing with the poor. In WCC publications and conferences a certain disenchantment with a one-sided liberation theology paved the way for a more holistic approach, in which, inter alia, serious attention for the ecological issues of the day was asked. Development, the argument went, makes little sense in a world that ceases to be the habitation of man. A new programme concentrating on the three issues of Justice, Peace, and the Integrity of Creation, is well on its way13.

Similarly in Catholic circles the radical liberation model of the 1980's is being questioned. Where are the results of all the combined efforts of liberation theologians? What is necessary today is a synthesis, a more holistic programme for tackling the challenges of world wide poverty.

In passing it may be noted that also in orthodox and evangelical as well as charismatic churches, the problem of the poor is currently receiving urgent attention. Orthodox churches, many of whom through the centuries have lived in situations where they were persecuted or marginalized themselves, always have had an interest in and sympathy for the poor and destitute. And in the evangelical Churches, especially since the publication of the Lausanne Report, many christians came to a new understanding of the inescapable social implications of the gospel of Jesus Christ ${ }^{14}$.

\section{THROUGH THE EYES OF THE DUTCH REFORMED CHURCH}

I may be forgiven for adding a few notes on developments within the Dutch Reformed Church (Nederduitse Gereformeerde Kerk) on these issues. How did the DRC perceive the problem of the poor? Did the church contribute to the process of development at all? For many years the DRC, for reasons only too well known, found itself often outside the larger ecumenical family, excluding itself from the privilege of partaking in the ecumenical discussions on these issues. Which does not mean that the church has not been busy struggling with the problem of poverty - not by a far stretch. Kritzinger ${ }^{15}$, in an article soon to be published, tells the fascinating story of the three approaches of DRC's involvement with uprooting poverty.

4.1 The first approach, or first phase, Kritzinger calls the structural approach, when the Dutch Reformed Church confronted with the appalling problem of the socalled "Poor Whites" in the 1930 's, set out vigorously to rectify the situation. Economically the Afrikaners, at the end of the Anglo-Boer War (1902), were in an extremely poor position. Many were unschooled and unskilled. Spiritually, morally, and physically, their situation deteriorated during the Depression Years. The (first) 
Carnegie Commission on Poor Whites calculated that, in the 1930's half the total white population were poor, some 300000 extremely poor. The DRC, deeply distressed by the plight of the people, was not hesitant to tackle the problem headon. They analysed the situation, discovering the structural causes at the root of the problem, and started a comprehensive process during which almost no distinction was made between religious, social, economical, and political issues. The church, on a religious level asked itself the question: how relevant to the needs of the people, is our message? On the social and cultural levels much was done for the upliftment of the Afrikaners, for the renewal of their cultural heritage. On the economic front a series of selfhelp schemes were introduced, ranging from establishing settlements, co-operatives, children's homes, etcetera, to pressurizing the government of the day into starting industries, to employ thousands of Afrikaners. On a political level the Churches lobbied and persuaded government into founding a brand new state department, minister and all, to care for the underprivileged in society. In many respects the church's involvement was a huge success, Kritzinger argues. But an unqualified success? No. The main reason was it's exclusivity. In principle it was not "an option for the poor", but a siding with "our own poor". The process was conceived to work for the Afrikaners - and it did. But the neighbours, the other South Africans, equally poor and destitute, were forgotten.

4.2 The second approach may be called the institutional approach. In its mission work since the middle of the previous century the DRC, as did many other churches and organizations at the time, followed a so-called "mission station approach" or a "comprehensive approach", by which the building of schools, the founding of hospitals and clinics, of old age homes and institutions for children, the lame and the deaf and the blind, was considered to be part and parcel of the gospel message of Jesus Christ. The love of God, it was stressed, needed to be proclaimed in word and deed.

When the Tomlinson Report (1955) brought the appalling conditions under which so many black South Africans in the Bantustans, as the black areas were called, to light, dozens of missionaries - consisting of ministers of religion, medical doctors, nurses, farmers, teachers, clerks - went into Northern and Eastern Transvaal, to the Transkei and Ciskei and Natal, building schools and hospitals, starting farms and institutions for the benefit of thousands. The church reacted to the inhumane situation caused by the forced relocation of people to the infamous village of Dimbaza in the Ciskei, establishing factories and workshops, to create work opportunities for the uprooted people. Evidently, to some missionaries, the enthusiasm for the development of black rural areas had an ideological ring to it. It fitted in nicely with the policy of the development of the "Bantustans" - a "noble cause" to many an Afrikaner in those days. But in spite of all that, Kritzinger says, 
one needs to lift your hat to a number of highly motivated missionaries, who recognized a need outside their own community - and reacted to that. What constitutes a pity, though, was the top-down philosophy of this approach; there was a lack of involvement of the local community in the planning, conception and execution of the work. Sites sometimes were chosen without consultation of the people, sometimes against their very wishes, from time to time in open competition with other churches or organizations. Local people were recruited and offered jobs, but usually in the lower echelons. The institutions - whether they were schools, hospitals or old age homes - were usually welcomed, but often remained foreign, strange operations. The local community seldom accepted ownership of the projects.

4.3 During the 1980's a radical new approach to development appeared in DRC circles, the so called community based approach. A growing disenchantment with the previous approach as well as the wider experience a number of officials in the DRC gained, coupled with the devastating drought in Northern Transvaal that reached crisis proportions in the 1980 's, forced the church to reappraise its policies, opened the door to renewal.

The Reverend E C D Bruwer with his CAN ("Church Aid to the Needy") Project became very much the centre of this community hased approach. "First listen, then respond", Bruwer summarized this approach. Church aid should be need-oriented, the initiative coming from the grass roots, he said ${ }^{16}$. The Church should act as a midwife, helping to bring about the birth of the possibilities inherent in the local community; or as a miner, bringing to the surface the riches already present in the community, but which are inhibited by the tragic results of poverty and oppression.

So much for history - ancient as well as recent history. The future lies ahead of us. What, then, is the role of the church in years to come, in combating poverty? If indeed, the church has a role to play? Reflecting on South African conditions, towards the end of their magnum opus, Uprooting Poverty, Francis Wilson and Mamphela Rampele, after discussing the many faces of poverty in our land, describing the many causes of poverty, make an interesting observation. In South Africa, where more then three quarters of the population consider themselves to be christians, it is inconceivable for the churches not to continue to play a part in the upliftment of the poor. Indeed, "despite its many limitations and failures, the christian church has a remarkable record down the centuries in creating and nurturing organizations aimed at serving and harnessing the energies of people in need ${ }^{17}$." 
How do we do that? How can Christians rise to the challenge? Paul, the apostle - I would like to suggest - had given us the answer many centuries ago. Faith, hope and charity, Paul used to say, are the solutions to most problems facing Christians wherever they are ${ }^{18}$. There is no better road to travel upon, if we, in future, want to play our part in combating poverty in our society.

\subsection{The road ahead must be a road of faith}

This is easier said then done. It is not always easy to define what faith in every concrete situation really means. If I understand the struggle of the churches to define their role vis-à-vis the poverty of our time correctly, it becomes evident that the church is not only facing an ethical challenge, but a gospel challenge. Reflecting on the poor is not so much an exercise in what we should do, but rather in what we as Christians truly believe. Once we recognize God as the God who has a special love in his heart for the poor, once we come to learn of Jesus' identification with the marginalized, nothing in our lives can ever be the same. We are continually challenged to redefine the true content and meaning, and implications, of our own faith. Nicholas Berdyayew 19 once wrote: "While the problem of my own bread is a material issue, the problem of my brother's bread is a spiritual issue".

Another, related, question we shall have to dare to face travelling down the road of faith is the following: In our missionary efforts in the past, in our endeavours to present God to others, have we succeeded in presenting a true picture of God, the God revealed to us in Scripture? Are we continuing to do so?

The authors of the widely read document, The Road to Damascus speaking for Christians in seven countries: South Africa, Namibia, South-Korea, the Philippines, El Salvador, Nicaragua and Guatemala - shocked the world with their observations: "The God whom the missionaries preached, was a God who blessed the powerful, the conquerors, the colonisers. This God demanded resignation in the face of oppression and condemned rebelliousness and insubordination. All that was offered to us by this God was an interior and other-worldly liberation. It was a God who dwelt in heaven and in the Temple, but not in the world".

"The Jesus who was preached to us was barely human. He seemed to float above history, above all human problems and conflicts. He was pictured as a high and mighty King... who ruled over us... His approach to the poor was therefore thought of as condescending. He condescended to make the poor the objects of his mercy and compassion, without sharing in their oppression and struggles... Jesus had no relevance to life ${ }^{20 "}$.

We may differ from this harsh critique of the message of missionaries through the years. We may find it one-sided and unfair. And it certainly is! But the nagging question remains: have we not perhaps, by not presenting our faith 
properly and relevantly given Third World Christians some reason to protest our message, our presentation of God?

Still another milestone on the road of faith has to do with the prophetic witness of the Church. Being a Christian, professing your faith in Christ, carries with it the responsibility - like the prophets of old, like Jesus Himself - to take a stand for truth and justice in society, to oppose every form of injustice, any ideology legitimizing injustice, in the name of our God, and of his message. Justice and peace go together, the one embraces the other (Psalm 85). You may not choose between the two, the bishops at Medellin emphasized. "Peace and Justice! Justice is the new name for Peace"21.

Reconciliation, putting a stop to the endemic violence in our land, has become the most important issue in South Africa - and rightly so. But reconciliation may never come cheap, glossing over the iniquities of the past. "Do you want peace", Augustine wrote, many centuries ago. "Then you have to look for justice as well. If you ask all men: 'Do you want peace?', the whole world will answer: 'Yes!, I love peace, I long for peace'. Be sure that you equally long for justice, because justice and peace are friends, the one embraces the other... they never fight each other"22.

Walking the way of faith, finally, means taking a long, hard look at yourself, at our traditional life-style, reflecting on such difficult issues as: should we unquestioningly accept the demands of the consumer society we have become used to, and addicted to, the life-style that taught us to look at the world, at other people, as commodities to be used and abused? Dare we, not so much for the sake of the poor, but for the sake of the gospel itself, adopt an alternative, a simpler, life-style? Do we understand what Paul's "isotes" principle demands of us today?

\subsection{The road ahead must be a road of hope}

To talk about hope, the Christian hope, seems totally unreal and unrealistic to many, chasing after the proverbial pie in the sky, to long for the second coming of Christ, to dream of a new heaven and earth as having nothing to do with the rough and tumble of every day life.

Nothing, of course, is further removed from the truth. The Christian hope is firmly fixed on both this and the ultimate, new world. In a world bereft of hope, the church has the solemn obligation to witness to its hope, not only for this world, but also for the world to come. People who know that they have been awarded citizenship in the kingdom of heaven can afford to take the kingdom of this world seriously. Those who live with a vision of the day when God will wipe away the tears from people's eyes, in a world where there will be no more death or grief or crying or pain (Rev 21:4), can resolutely labour at wiping away the tears from the 
eyes of those around them. They can alleviate the grief and pain and suffering among the poor and the marginalized of this world and erect signs of the Kingdom to come.

Living in hope means to proclaim to the poor that God is sovereign, that ultimately $\mathrm{He}$ - not the powers that be - decides their future. Hope, therefore, means never giving up on this world, nor on the church, neither on one another. Hope entails caring for creation, responsible stewardship of the good earth and its resources. Hope means laughing for joy although some see little reason for hope in the greyness of a squatter camp. Living in hope means campaigning for justice, standing up to the authorities, learning from Mary's Magnificat that God in sending Jesus "has brought down mighty kings from their thrones, and lifted up the lonely. He has filled the hungry with good things and sent the rich away with empty hands" (Luke 1:52f) ${ }^{23}$.

However, if the church wants to impart a message of hope to the world, something of that hope and of the new dispensation should take shape in the church herself. The church is the "single new humanity" (Eph 2:15) out of Jews and Gentiles; and the process which gives birth to the new humanity... a sign of things to come $^{24}$. This description, Paul's description, of the church, it seems to me, aptly describes the so called base communities, or ecclesial communities, which have been flourishing all over Latin America as well as in other parts of the world in the past decades, communities where the poor and the destitute, people who over a long period of time have lost all expectations, were brought together, to live and work together, to pray and worship together, to rekindle a flame of hope in one another ${ }^{25}$. There is no reason why a repetition of this experiment should not be attempted in South Africa, why people with courage and imagination and hard work should not be able to start such base communities in our country, in our time. Alexandra and Soweto, Kwa Mashu and Cross Roads can do with a handful communities of hope. Along the road of hope people regain their vision, reminding each other that God, the Powerful and Almighty God, has the whole world in his hands; that the final decision on what the future of our society, our families, our churches, will be, does not rest with Pretoria or Cape Town, nor with the Multi-party Forum in the World Trade Centre, it rests with God. He, ultimately, will decide. God, our Father, is in charge.

Vision, according to Wilson and Ramphele ${ }^{26}$, is what the marginalized needs. For vision means empowerment - and that, above all, is what the church should be able to provide. Under the most adverse circumstances, Christians may like Mother Theresa of Calcutta - erect of signs of hope. The church most certainly owes the world, the poor as well as the not-so-poor, white as well as black South Africans, hope! 
The church not only owes the world hope. It owes the world love! In the words of David Bosch:

"The love the Church has experienced ought to be passed on to others. The love of Christ constitutes the model and the measure of the Church's love to the world. Christ's love revealed its deepest dimension on the Cross. It will not be different with the Church.

"The Cross is the hall-mark of the Church, as it was of Jesus. The proofs of Jesus' identity were his scars. Because of them, the disciples believed (John 20:20). Likewise, because of the scars of the Church the world will believe.

"Too often precious little of this was apparent in the past. The Cross was the symbol of the power and victory of the Church, not of her weakness, wounds and defeats. For precisely this reason the Church in many respects stands judged before the world. She has forgotten that she is called to live according to the example of One who said, 'Here am I among you like a servant' (Luke 22:27)"27.

This principle, fortunately, scores of Christians, through the centuries have understood and acted upon. Faith and hope need to be made practical, they realised - by acts of love. "What God the Father considers to be pure and genuine religion is this: to take care of orphans and widows in their suffering, and to keep oneself from being corrupted by the world" (James 1:27).

Many churches and agencies, in South Africa, are involved in doing this: Church Aid in Need, NOVA, the work of the Church of the Province, of the Catholic Church and the SA Council of Churches, and many others, all of them emulating the example of the Good Samaritan who truly understood what love was all about. The gospel story provides for a very practical agenda for every church in the country: "The Samaritan (the Church!) saw the man, stripped of all his possessions, beat up, half dead... and his heart was filled with pity, He went over to him, poured oil and wine on the wounds, and bandaged them... He put the man on his own animal and took him to the inn... He took out two silver coins. 'Take care of the man,' he said to the inkeeper. 'When I come back... I will pay you whatever else you spend on him" (Luke 10:25-37).

To translate this into the realities of South Africa, that is the challenge!

Of course, no christian, no church can walk the road of faith and hope, especially the road of love alone. On this road we need each other desperately. Caring for the poor, answering to the demands of development has to be an ecumenical venture. It is gratifying to know that this is increasingly happening in the 
country. Catholics and Anglicans, Baptists and Charismatics, Presbyterians and Lutherans, Gatjieponders and Stoepsitters and Doppers ${ }^{28}$ have no other option, but to take one another's hands in grappling with the problems and challenges of poverty.

Of course there will be a price to pay. That is to be expected - though not always welcomed. "Comfortable Compassion?" (with a huge question mark!) is the title of a recent book on the difficulties Western christians have to face, when they have to learn to kneel down, to minister to the poor and the suffering of the world 29. For the man in his comfortable chair, on the cover, looking at the umpteenth face of a hungry, destitute Ethiopian mother and child, it does not came naturally. But, that is the way of our Lord.

"Where shall I find the Messiah? Where can I meet Him?" Rabbi Joshua Ben Levi - according to an ancient Talmudic story - asked the prophet Elijah. "Go to the poor and the sick, to the lepers at the gate of the city. Look for Him there," the prophet responded. "What is the Messiah doing there?" the rabbi exclaimed in astonishment. Elijah answered: "You will find Him, kneeling down, dressing the wounds of the ill, comforting the dying, feeding the hungry. That is what He does"30!

By this we recognize our Messiah - even today.

By kneeling down with him, He recognizes us as his disciples - even today.

\section{NOTES:}

1 Paper read at the symposium on the Combating of Poverty, hosted by the Centre for Continual Theological Training, Theological Faculty of the DRC (Ned Geref Kerk), University of Pretoria, May 7, 1993.

2 W S Prinsloo, "Die arme in die Ou Testament", Die Sendingblad (April 1990), 18-19; cf A B du Toit, "Wat sê die Nuwe Testament oor armoede?", Die Sendingblad (April 1990), 22-23; Julio de Santa Ana, Goed Nieuws voor die Armen, Kampen 1981, 10-12; John Harvey, Bridging the gap: Has the Church failed the Poor? Edinburgh 1987; P L Pemberton and D L Finn, Towards a Christian economic order, Minneapolis 1985; R J Sims, Wealth and poverty, selfsupport and sharing in the Churches worldwide, Pasadena 1988.

3 Quoted by D J Bosch, Transforming mission. Paradigm shifts in Mission, Maryknoll 1991, 436. The reader will soon recognize to what extent the author is indebted to David Bosch in preparing this article.

4 W S Prinsloo, Die Sendinghlad (April 1990), 18-19; Leonardo Boff, When theology listens to the poor, San Francisco 1988. 
A B du Toit, Die Sendingblad (April 1990), 20-23; cf Olu Alana, Reconsidering the poor by gospel norms, AFER 32/4 (1990), 193-201; D J Bosch, "Mission in Jesus' way: a Perspective from Luke's Gospel", Missionalia 17/1 (1989), 3-21; J De Santa Ana, op cit, 22-46; Peter Seccombe, Possessions and the poor in Luke, Linz 1982; Timothy Gorringe, "Amen, Komm Herr Jesus: Eucharistie, Eschatologie und die Option für die Armen", Evangelische Theologie 50/1 (1990), 26-35.

6 D J Bosch, op cit, 433; J De Santa Ana, op cit, 1981, 72-92.

7 D J Bosch, op cit, 433; cf Julio De Santa Ana, Separation without hope, Maryknoll 1980, 3-29.

8 D J Bosch, op cit, 433-435.

9 D J Bosch, op cit, 433-435; J J Kritzinger, Die rol van religie in ontwikkeling, Navorsingsverslag, Universiteit van Pretoria, Deel I en II, Pretoria 1991.

10 D J Bosch, op cit, 433-435.

11 D J Bosch, op cit, 435-436; cf D Möller: "Die Wêreldraad van Kerke en Ontwikkeling", "Die Rooms Katolieke Kerk en Ontwikkeling" and "Die Evangelicals en Ontwikkeling" (Three Study Reports) in: J J Kritzinger Die Rol van Religie en Ontwikkeling, Navorsingsverslag, Universiteit van Pretoria, Pretoria 1991; F J Verstralen, "De kerk, de armen en ontwikkeling" in: De armen, de kerk en ontwikkeling (Verslag, IMMO Studiedag te Zeist), Zeist 1983, 1-19; Norbert Greinacker, Die Kirche der Armen, München 1980, 79 109.

12 Quoted by D J Bosch, op cit, 435-436; cf Kenneth Slack, Hope in the desert, Geneva 1986, 1-29.

13 J J Kritzinger, op cit, 40; D J Bosch, op cit, 434; D Moller, op cit, 329-378; Karl Osner, Kirche und Entwicklungshilfe, Kevelaar 1985; Raymund Fung, "The Gospel is not for sale", The Princeton Seminary Bulletin 10/1-3 (1990) 61-70.

14 D J Bosch, op cit, 437; cf D Moller, op cit, 421-447; Julio de Santa Ana, Separation without hope, Maryknoll 1980, 60-68.

15 J J Kritzinger, "The Dutch Reformed Church and Development" (manuscript soon to be published, University of Pretoria) 1993, 1-19.

16 E C D Bruwer, "The Community of our Elephant", and "Church Aid in Need". Papers read at the REC Symposium on Poverty, Mamelodi, Pretoria (Unpublished), Pretoria 1990.

17 Francis Wilson \& Mampela Ramphele, Uprooting poverty. The South African challenge, Cape Town 1989, 302.

181 Thessalonians 1:2-3. 
20 Third World Christians from Seven Nations; The Road to Damascus. Kairos and Conversion, Johannesburg 1989, par 30-31. For a critique of this document, cf B Engelbrecht, "A call for the restoration of orthodoxy in South African Theology", HTS 47/4 (1991), 151-166.

21 J De Santa Ana, op cit, 120.

22 J De Santa Ana op cit, 120. Freely translated from the Dutch text.

23 REC, Acts of the Council, Athens 1992, 314. The text of this report was drafted by the author, and therefore used in this article.

24 D J Bosch, op cit, 241.

25 G F Kelly "Radical Faith and the Social Liberation of the 'Little People' in the Americas", The Princeton Seminary Bulletin, 12/2, 214-230. Cf Roel Schaull, "The Christian Base Communities and the Ecclesia Reformata Semper Reformanda" in The Princeton Seminary Bulletin, 12/2 (1991), 201213; Ranjit de Silva, "House Church Movement catches on among Sri Lanka's urban and Rural Poor", Evangelical Mission Quarterly, 27/3 (1991) 274-278; John Harvey, Bridging the Gap: Has the Church Failed the Poor? Edinburgh 1987.

26 F Wilson, Ramphele, op cit, 1989, 302; W V van Deventer, "Gemeente en Gemeenskapsarmoede", NGTT 28/2 (1987) 176-181.

27 D J Bosch, Witness to the world, Atlanta 1980, 247-248.

28 The terms "Gatjieponder", "Stoepsitter", and "Dopper" refer, respectively to the Ned Geref Kerk, the Ned Hervormde Kerk and the Gereformeerde Kerk.

29 Charles Elliot, Comfortable Compassion? Poverty, Power and the Church, London 1987.

$30 \quad$ P G J Meiring, "Vigs - die keer deur 'n sendingkundige bril" in Skrif en Kerk $10 / 2$ (1989), 155-167. 